Драгица Кољанин

Универзитет у Новом Саду

Филозофски факултет

Одсек за историју

mbkoljanin@gmail.com
Оригинални научни рад

примљено: 28. јун 2011

прихваћено: 1. октобар 2011

\title{
КА НОВОЈ ИСТОРИЈСКОЈ СВЕСТИ: НАСТАВА ИСТОРИЈЕ У ОСНОВНИМ ШКОЛАМА У СРБИЈИ 1945-1947*
}

Сажетак: По преузимању власти комунисти су интензивирали активности у сфери културе и просвете. У посебном фокусу било је основно образовање које је обухватало најбројнију ђачку популацију, као и настава историје. Ово истраживање се бави анализом тока доношења одлука, њиховом применом и расправама које се вођене између централних југословенских органа и Министарства просвете Србије о циљевима наставе историје у основној школи, њеним плановима и програмима, начинима реализације и посебно питањем уџбеника. Детаљно су анализирани планови и програми наставе историје у основној школи из 1945. и 1947. Рад је написан на основу архивских истраживања, објављених историјских извора и савремене периодике.

Кључне речи: Југославија, Србија, основна школа, настава историје, наставни програми, уџбеници.

После победоносног ослободилачкиг рата и револуционарне промене друштвеног система у Југославији 1941-1945, нова друштвена елита је настојала да овековечи новостворени систем, како на политичком тако и на идеолошком пољу. Како је власт свој легитимитет заснивала управо на променама насталим током ослободилачког рата и револуције, овај историјски период је добио посебно место у јавном дискурсу. ${ }^{1}$ На њега се гледало као на главно средство за обликовање историјске свести младих генерација тако да је она добила и посебно место у школској настави историје.

Како је основношколски узраст ученика формативни период у коме се усвајају основни појмови и знања о друштвеној заједници и њеној историји,

\footnotetext{
* Рад је настао као фазни резултат републичког пројекта број 177002 под називом Војвођански простор у контексту европске историје.

${ }^{1}$ Marija Obradović, „Narodna demokratija“ u Jugoslaviji 1945-1952, Beograd 1995, passim; Ljubodrag Dimić, Agitprop kultura. Agitpropovska faza kulturne politike u Srbiji 1945-1952, Beograd 1988, passim.
} 
креатори нове просветне политике су и у периоду од 1945. до 1947. највећу пажњу посвећивали „неговању тековина народноослободилачког рата“ посебно у оквиру наставе историје. Међутим, просветне власти су се суочиле са бројним препрекама у организовању наставе. ${ }^{2}$ Један од главних проблема у просветној реформи коју је спроводила нова власт био је недостатак одговарајућих уџбеника историје за основне школе, које је требало „идејно“ прилагодити новим приликама. Убрзо се показало да су резултати ревизије целокупне историјске науке у духу марксизмалењинизма били далеко од очекиваних и прижељкиваних.

Одмах по формирању нове владе Министарство просвете ДФЈ је настојало да изврши темељну промену у настави историје. Први корак је било потпуно одбацивање уџбеника историје из времена Краљевине Југославије. Министарство је истицало да је један од најпречих задатака израда нових уџбеника историје и писање историје Народноослободилачке борбе. Недељу дана после формирања Привремене владе ДФЈ, 14. марта 1945, Министарство просвете ДФЈ је упутило Повереништву за просвету Србије акт у којем је наведено следеће: „На основу брижљиво скупљеног материјала у појединим федералним јединицама, који ће систематски и објективно бити обрађен, моћи ће се приступити изради историје народно-ослободилачког покрета у читавој Југославији и то ће извршити нарочита комисија. Исто тако је потребно приступити објективном обрађивању историје наших народа за наставу у нашим школама. У старој Југославији се до сада учила историја наших народа необјективно и једнострано. Потпуно је био занемарен утицај друштвених снага и напредних идеја времена у историском развоју југословенских народа. Нису била довољно обрађена дела наших великих заслужних људи нити њихова улога у нашем друштву. Уџбеници за историју у старој Југославији, ни по грађи ни по својој обради, ни по својој методи не одговорају нити се могу употребити у нашим школама. Зато се намеће и ту битна потреба да се већ сада приступи изради уџбеника у свакој федералној јединици“. ${ }^{3}$

Министарство просвете ДФЈ је 10. априла 1945. упутило Министарствима просвете федералних јединица распис у вези са израдом новог плана и програма за редовну наставу из историје. Осим ових иницијатива и налога „одозго“, настојало се и на томе да се чује глас „одоздо“, односно да се изјасне и сами наставници историје о томе какве треба да буду промене. Наставни савет Министарства просвете Србије je 22. маја 1945. тражио је од свих директора школа да наставници историје „писменим путем дају своје предлоге и сугестије за израду плана и програма за редовну наставу из историје у идућој школској години“. ${ }^{4}$

\footnotetext{
${ }^{2}$ Томислав Богавац, Школство у Србији на путу до реформе (развој икола 1945-1975), Београд 1980, 4855; Драгомир Бонџић, Просвета и наука у Србији 1945-1990, Историја 20. века 2, Београд 2008, 398-399; Момчило Павловић, Школство у Србији 1945-1950, Образовање Срба кроз векове, Београд 2003, 290292.

${ }^{3}$ Архив Југославије, фонд Министарство просвете Владе ФНРЈ, Београд, фонд 313, фасцикла 2 (АЈ, 3132).

${ }^{4}$ AJ, 313-2.
} 
Министарство просвете ДФЈ није било задовољно сарадњом са федералним јединицама на остваривању нове просветне политике. Министарство просвете није ни до 25. маја 1945. примило од федералних држава ниједан извештај. Министар просвете Владислав Рибникар је о томе известио Председништво Министарског савета ДФЈ и друге највише органе државе, при чему је нагласио следеће: „Овакав поступак не само да онемогућава исправан рад овог министарства, већ је поуздан доказ да рад у дотичној јединици не тече како би требало. Не одашиљањем извештаја министарства просвете тих федералних јединица онемогућавају да се просветни рад стабилизује, среди и да одговори својим задацима“. ${ }^{5}$

Министарство просвете Србије је у другој половини маја 1945. донело наставни план и програм за основне школе са методским упутствима за обраду појединих наставних предмета који је објављен и као посебно издање. ${ }^{6}$ Планом је предвиђено да се изводи настава из 11 предмета: српски језик, историја, земљопис, рачун, природа и привреда, ручни рад, цртање, писање, певање, телесне вежбе и веронаука. Историја се изучавала у трећем разреду са три часа недељно (од укупно 27) и са четири часа недељно у четвртом разреду основне школе (од укупно 29). Програмирање градива у трећем и четвртом разреду је била комбинација хронолошко прогресивног принципа и принципа концентричних кругова. Дат је потпуно разрађен (детаљни) план рада где је по наставним темама распоређен годишњи фонд часова наставе историје.

Наставни план за основне школе у Србији 1945/1946.

\begin{tabular}{|l||c|c|c|c||}
\hline \multirow{2}{*}{ Предмети } & \multicolumn{5}{|c|}{ Разреди } \\
\cline { 2 - 5 } & I & II & III & IV \\
\hline Српски језик & 10 & 10 & 7 & 7 \\
\hline Историја & - & - & 3 & 4 \\
\hline Земљопис & - & - & 2 & 3 \\
\hline Рачун & 6 & 6 & 5 & 5 \\
\hline Природа и привреда & - & - & 4 & 4 \\
\hline Ручни рад & 1 & 1 & 1 & 1 \\
\hline Цртање & 1 & 1 & 1 & 1 \\
\hline Писање & 1 & 1 & 1 & 1 \\
\hline Певање & 1 & 1 & 1 & 1 \\
\hline Телесне вежбе & 1 & 1 & 1 & 1 \\
\hline Веронаука & 1 & 1 & 1 & 1 \\
\hline Укупно & 22 & 22 & 27 & 29 \\
\hline
\end{tabular}

\footnotetext{
${ }^{5}$ AJ, 313-2-562.

${ }^{6}$ Нови наставни план и програм за основне школе са методским упутствима за обраду појединих наставних предмета, Београд 1945.
} 
У наставном плану циљ наставе историје је дефинисан у складу са основним идеолошким опредељењима нове власти: „Упознавање ђака са историјском прошлошћу народа, развијање љубави према отаџбини и њеним народима, учвршћивање братства и јединства наших народа као и безграничне оданости отаџбини и развијање мржње према свима онима који су против јединства наших народа и слободе наше отаџбине. Ова настава треба да код ђака створи уверење о непрестаном друштвеном развијању, као и да су народи носиоци историског и друштвеног развитка. Исправно упознавање ђака са историским догађајима и друштвеним развитком народа послужиће развитку његових социјалних и националних осећања. Оно ће такође допринети оспособљавању младих генерација за правилно и тачно вршење грађанских дужности и права. Ученици се морају упознати са народно-ослободилачком борбом која је проистекла из народа чија је борба праведна и која је спасла наше народе, њихову част и обезбедила им бољу будућност“.

Следила су методичко-дидактичка упутства о извођењу наставе. Тражено је да се историјска настава обрађује „хронолошким редом историских догађаја и што приступачнијим начином према узрасту и духовној моћи ученика. /.../ Приликом обраде историског градива не треба се ограничити само на уџбенике, већ развијајући љубав и интерес према овом предмету, њихово знање употпуњавати и грађом, која ће у већој мери расветлити догађаје“. ${ }^{7}$

У настави трећег разреда на три часа (11,1\% од укупно 27 часова) недељно обрађиван је период од праисторије до Првог српског устанка. Следио је период од стварања Југославије до Народноослободилачког рата и стварања народне власти. Препорука је била да се углавном изучава завичајна и национална историја, односно историја Србије. У трећем разреду обрађивано је девет тема: 1. Упознавање са праисторијским развитком; 2. Постојбина старих Словена и живот у њој; 3. Сеоба Јужних Словена; 4. Живот и обичаји Јужних Словена у новој постојбини; 5. Примање хришћанства и прва писменост; 6. Стварање првих српских држава: Немањићи, Косовска битка, Краљевић Марко, робовање под Турцима и Први устанак (укратко); 7. Стварање старе Југославије. Други светски рат и капитулација; 8. Окупација (живот под окупацијом); 9. Партизани и Народноослободилачка борба.

За обраду наведених тема, од укупно 111 часова, предвиђено је 69 (62,2\%) часова, док су 42 часа предвиђена за утврђивање и понављање градива. За обраду историје Југославије предвиђена су 34 (49,3\%) часа, односно половина часова предвиђених за обраду новог градива. Према програму, изучавање теме Другог светског рата ограничено је углавном на територију Србије. „Укратко дотаћи се другог светског рата и капитулације. Недела и злочини окупатора (стрељање, вешање и масовно убијање у Јајинцима, Крагујевцу, Краљеву и Мачви). Партизани

\footnotetext{
${ }^{7}$ Нови наставни план и програм за основне школе са методским упутствима за обраду појединих наставних предмета, Београд 1945, 10.
} 
и народно-ослободилачка борба. Вођ народно-ослободилачке борбе Јосип Броз Тито. Народна власт“.

Програмирање градива у трећем и четвртом разреду је била комбинација хронолошко прогресивног принципа и принципа концентричних кругова. У трећем разреду изучавање националне историје завршавало се Првим српским устанком. Затим се прелазило на изучавање историје Југославије, при чему је највећа пажња посвећена Народноослободилачкој борби (20 часова, 29\% од укупног броја часова за ново градиво).

У четвртом разреду историја се изучавала на четири часа (13,8\% од укупно 29 часова) недељно. Од укупно 148 часова, предвиђена су 94 часа $(63,5 \%)$ за обраду новог градива, а 54 часа за утврђивање и понављање градива. Обрађивано је укупно 7 тема: 1. Немањићи; 2. Косовска битка и робовање под Турцима; 3. Први и Други устанак; 4. Ратови за национално ослобођење од 1876 до 1918 године; 5. Стварање старе Југославије и њено политичко уређење; 6. Други светски рат и Народноослободилачка борба; 7. Кратак преглед историје других федералних јединица (Хрватске, Словеније, Црне Горе, Босне и Херцеговине и Македоније).

Уочљиво је да је националној историји Србије, од Немањића до формирања Југославије, посвећен већи број часова, 50 часова (53,2\%). Периоду од стварања Југославије до краја Народноослободилачке борбе посвећена су 24 часа (25,5\%), од тога Народноослободилачкој борби, као и у трећем разреду, 20 часова (21,3\%). У оквиру пете теме предвиђена је обрада следећих наставних јединица: стварање Југославије, политичко уређење, устав из 1921 (неравноправност народа, противнародна владавина). У шестој теми биле су следеће наставне јединице: Други светски рат, капитулација југословенске војске, окупација Југославије од стране фашистичке Немачке и Италије, недела и злочини окупатора, народни издајници и њихова служба окупатору, народни устанак у Србији, Црној Гори 1941. године, партизани, њихова борба, оснивање Народноослободилачке војске, вођ Народноослободилачке борбе Јосип Броз Тито, прво заседање Антифашистичког већа у Бихаћу 1942. године, његове одлуке, организовање народне власти, прва антифашистичка скупштина Србије и њене одлуке, стварање Федеративне Демократске Југославије и учвршћивање јединства свих народа Југославије. ${ }^{8}$

Очигледно је било да је наставни план и програм врло детаљно разрађен, али и да је био врло захтеван. Осим уводних наставних јединица из опште историје у трећем разреду, изучавала се национална историја, и то углавном историја Србије. У последњим наставним јединицама о историји Југославије и Народноослободилачкој борби, историја Србије је делом уклопљена у историју Југославије. У четвртом разреду дате су кратке историје других народа, односно других федералних јединица.

\footnotetext{
${ }^{8}$ Нови наставни план и програм за основне школе са методским упутствима за обраду појединих наставних предмета, Београд 1945, 12-13.
} 
На првом заседању Просветног савета при Министарству просвете ДФЈ августа 1945. вођена је и расправа о уџбеницима историје. Показало се да нема приручника за историју Народноослободилачке борбе, као и да су федаралне јединице испољиле велики немар у прикупљању грађе за њено писање. Изнето је и мишљење да мора да се изврши темељна ревизија уџбеника историје јер су тумачења у њима неприхватљива. „Међутим, потреба уџбеника у Србији толика је, да је потребно поступити најбржим начином, а тај је начин израда путем комисије“. Прихваћен је став да федералне јединице издају посебне уџбенике. ${ }^{9}$

Министар просвете ДФЈ Владислав Рибникар је 28. септембра 1945. прописао Оквирни наставни план и програм за основне школе. Овај план и програм у понечему се разликовао од оног који је објавило Министарство просвете Србије. Преовлађујући принцип у Оквирном плану је био хронолошко прогресивни и једина наставна тема која се понављала и у трећем и у четвртом разреду била је тема Народноослободилачке борбе. Верска настава је постала необавезан предмет.

Оквирним планом и програмом је предвиђено да се изводи настава из 10 предмета: Народни језик, Историја, Земљопис, Природне науке, Рачун, Цртање, Певање, Телесно васпитање, Лепо писање и Верска настава. Предвиђено је да се настава историје изводи у трећем разреду са два часа (8,33\% од укупно 24) и у четвртом са три часа (11,5\% од укупно 26) недељно. Оквирним планом је наведен следећи циљ наставе историје: „Упознавање ученика са историјском прошлошћу наших народа и наше домовине Југославије. Развијање љубави и оданости према домовини и њеним народима. Учвршћивање братства и јединства наших народа и свих тековина народно-ослободилачке борбе. Васпитање деце у непомирљивој мржњи према непријатељима домовине, према свима онима који раде на уништавању тековина НОБ“. ${ }^{10}$ У трећем разреду предвиђена је обрада историје федералне јединице са којом је требало да се повежу најважнији моменти из историје јужнословенских народа у Југославији. Изучавање би отпочело са праисторијом, животом старих Словена у старој постојбини, њиховом сеобом и животом у новој постојбини. Следила је историја првих јужнословенских држава, хришћанство и писменост, прва словенска држава (Само), почеци хришћанства међу Јужним Словенима, карантански Словени, Панонска и Далматинска Хрватска, Људевит Посавски и борба против Франака, Бугари, Срби - Рашка и Зета, друга македонска држава - Самуило, Ћирило и Методије и његови ученици - Климент и Наум, прва писменост. Следећа тема је била „Устанак и тековине борбе за ослобођење наших народа. Тито“.

И у четвртом разреду би се обрађивала историја народа федералне јединице са којом је требало да се повежу најважнији моменти из историје јужнословенских народа у Југославији. У свакој федералној јединици (Србија, Хрватска, Словенија,

\footnotetext{
${ }^{9}$ АJ, 313-3, Записник вођен на првом заседању Просветног савета при Министарству просвете савезне владе, Београд, 6-14. августа 1945.

${ }^{10}$ AJ, 313-4, Оквирни наставни план и програм за основне школе Демократске Федеративне Југославије, Београд, 28. септембар 1945.
} 
Босна, Црна Гора, Македонија) обрађивана је њена средњовековна историја до губитка државне самосталности. По истом моделу обрађивало би се пропадање средњовековних држава и потпадање под страну власт, њихови покрети и борбе за ослобођење. Следили су Балкански рат, Први светски рат, стварање Југославије, Југославија од 1918. до 1941. На крају су биле теме Други светски рат, слом Југославије, борба за ослобођење и тековине НОБ.

Оквирним наставним планом и програмом прописан је и наставни план за мањинске школе. Оне су имале наставне предмете као и остале школе, с тим што су имале и предмет језик федералне јединице у којој мањина живи. Настава из тог предмета изводила се у трећем и четвртом разреду са по три часа недељно. Предмет Историја се предавао као Историја Југославије са историјом народа коме мањина припада, а број часова је био исти као и у осталим школама. Предмет земљопис се предавао као Земљопис Југославије са земљописом народа коме мањина припада. Наставни предмет Верска настава је био необавезан.

Министар просвете је прописао да овај Оквирни наставни план и програм ступа на снагу од школске 1945/1946. године на целом подручју ДФ Југославије. Он је нагласио да овај наставни план и програм представља максимум. „Министарство просвете федералне јединице, уколико је потребно, израдиће минимални наставни план и програм, тј. заокружиће градиво“. Нагласио је и да се од тога изузима настава историје: „Назначени програм историје не може се скратити, тј. све градиво треба повезати са националном историјом народа федералне јединице“..11

Према извештају Одељења за школство Министарства просвете ДФЈ за септембар 1945, Оквирни наставни план и програм упућен је министарствима просвете свих федералних јединица. Израђен је и програм за више основне школе и требало је да буде упућен федералним јединицама октобра 1945. Израђен је и програм за српски или хрватски језик у мањинским школама као и наставни план за мањинске школе. Они су такође упућени министарствима федералних јединица. ${ }^{12}$ Према извештају истог одељења за октобар 1945, федералне јединице су биле дужне да донесу детаљне наставне планове и програме на свом подручју. Међутим, Министарство није имало податке да је то и спроведено и било је упознато са тим „да федерална Србија још не ради по новом наставном плану и програму“. ${ }^{13}$ Ни у децембру 1945. у основним школама у Србији није се радило по новом, него по старом наставном плану и програму из 1944/1945. године. Министарство просвете ДФЈ није било задовољно како се остварује просветна политика у основним школама. „Да би се остварио јединствени школски систем неопходна је координација по свим питањима основне школе од плана и програма па до израде уџбеника, а то се у овом питању нарочито осећа.“14

${ }^{11}$ AJ, 313-4, Оквирни наставни план и програм за основне школе Демократске Федеративне Југославије, Београд, 28. септембар 1945.

12 AJ, 313-3.

${ }^{13}$ Исто.

${ }^{14}$ Исто. 
Показало се да се велики број школа не придржава наставног програма историје. Због тога је Министарство просвете ДФЈ тражило да се са таквом праксом прекине. Главни разлог забринутости Министарства било је свођење целокупне наставе историје на Народноослободилачку борбу која је при томе, по његовој оцени, приказивана крајње формалистички, чиме се губио значај њених порука. Помоћник министра просвете Мартин Менцеј је 21. јануара 1946. упутио свим народним републикама акт где је наведено да се установило да се „у многим школама уместо градива историје предвиђеног новим програмом предаје још увек само историја НОБ. То се је исто радило и током прошле 1944/1945 године. Та се пракса показала потпуно некорисном и непедагошком, јер је већи део наставника, непознавајући ширину тог предмета, сводио сав рад на набрајање офанзива, залазећи у непотребне детаље и учење напамет имена места и села где су се водиле борбе, кретање наших /и/ непријатељских јединица, имена фашистичких дивизија итд. итд. При томе се занемарила суштина и значај НОБ. Није се залазило дубље у опште историске проблеме, који су у непосредној вези са борбеним покретом наших народа и са драгоценим тековинама које су у тој борби извојеване“. Тражено је да се прекине са таквом праксом и да се школе придржавају плана и програма који им је достављен. ${ }^{15}$

Оквирни наставни план и програм за наставу у основним школама од 28. септембра 1945. давао је само опште смернице, а наставни планови и програми доношени по њему били су привремени. Доношењем Устава ФНРЈ 31. јануара1946. послови из области културе и просвете су подељени. Министарство просвете ДФЈ је радило до доношења новог устава, а 8. фебруара 1946. формирана су два нова органа управе за област просвете и културе: Комитет за школе и науку и Комитет за културу и уметност при Влади ФНРЈ. ${ }^{16}$

Председник Комитета за школе и науку Борис Зихерл тражио је 20. јуна 1946. да министарстава просвете народних република изврше измене и допуне тих планова за следећу школску годину. ${ }^{17}$ Б. Зихерл је у свом чланку у стручном часопису Савремена школа посебно истакао питање квалитета уџбеника за основне школе. Навео је да ни написани уџбеници не задовољавају у квалитативном погледу. „Има у њима још много погрешног схватања суштине народноослободилачког покрета, експериментисања, погрешног односа према нашем фолклорном богатству и шаблонизације“. ${ }^{18}$

На темељу мишљења министарстава народних република, Комитет је донео измене и допуне наставних планова и програма за основне школе за 1946/1947. школску годину. Извршена је прерасподела наставног градива између трећег и

15 АЈ, 313-3-97; Културна политика Југославије 1945-1952. Зборник докумената, приредили Бранка Докнић, Милић Ф. Петровић, Иван Хофман, књ. 1, Београд 2009, 249.

${ }^{16}$ Службени лист ФНРЈ, бр. 13/1946.

$17 \mathrm{AJ}, 315-24-79$, Претседник Комитета за просвету и науку, министарствима просвете свих народних република, Београд, 20. јун 1946.

${ }^{18}$ Борис Зихерл, Задаци намег школства и научних установа, Савремена школа, 3, септембар 1946, 150. 
четвртог разреда у складу са хронолошко прогресивним принципом и изостављене су неке наставне јединице. Из програма за трећи разред цело градиво под насловом „Устанак и тековине борбе за ослобођење нашег народа“ пребачено је у четврти разред у наставну јединицу о Народноослободилачкој борби. ${ }^{19}$

У складу са захтевима Комитета за школе и науку, министаства просвете народних република су и наредне школске године, 1947/1948, вршила измене и допуне у наставним плановима и програмима. У наставном програму историје за основне школе у Србији извршене су мање измене и сажимања градива у трећем разреду, а веће су измене биле у програму за четврти разред: „Програм из историје за IV разред знатно је скраћен. То је постигнуто углавном изостављењем поглавља која се односе на историју Хрвата, Словенаца, Црногораца и историју Босне и Херцеговине, јер то градиво у тој опширности обухватају програми дотичних република. /.../ Историја осталих југословенских народа додирнута је само уколико је повезана са историјом Срба - нарочито од првог светског рата и Народноослободилачке борбе“. ${ }^{20}$

На тражење Комитета за школе и науку при Влади ФНРЈ, Наставни савет Министарства просвете Србије доставио је почетком децембра 1947. мишљење о наставним плановима и програмима и уџбеницима за основне школе и предлоге за њихово побољшање. Поређењем наставних планова и програма република, закључено је да су они слични, али да у њима треба јаче нагласити фактор братства и јединства. „Идеја братства и јединства наших народа истакнута је у програмима свих народних република као један од задатака историске наставе. У свим програмима предвиђено је да се о братству и јединству говори кроз наставно градиво историје, кад се говори о народно-ослободилачкој борби. Али, ма како било наглашено у програмима да се братство и јединство обради кроз наставу историје то није довољно. У њој се историја братства да обрађивати кроз целу историску наставу, како на моментима из наше прошлости, који су позитивно утицали, тако и на онима који су били негативни““. ${ }^{21}$ Као недостатак програма наведен је и изостанак упутстава за њихово спровођење.

Наставни програми из историје у Србији и осталим републикама су се разликовали у методичком приступу. У Србији је историја обрађивана по прогресивно хронолошком принципу: у III разреду до пада под турску власт, а у IV разреду од пада под турску власт до савременог доба. У програмима других република историја се обрађивала по принципу концентричних кругова. У Србији се посебна пажња посвећивала уџбеницима, а показало се да је и даље најактуелније било питање уџбеника историје за основне школе. „Питање уџбеника је најслабије место у нашим школама. За историју немамо уџбенике, а за све остале предмете су

19 AJ, 315-24-105, Комитет за просвету и науку при Влади ФНРЈ, свима министарствима просвете народних република, Београд, 14. август 1946.

${ }_{20}$ АJ, 315-24-196, Министарство просвете НР Србије, Комитету за школе и науку при влади ФНРЈ, Београд, 29. септембар 1947.

${ }^{21}$ AJ, 315-22-290 до 291. 
већ издати или су у штампи“. У закључку свог извештаја Министарство просвете је навело да није било никакве координације између министарстава просвете народних република у вези са програмом, уџбеницима, методиком, приручницима и слично и предложило је израду заједничког једнообразног програма и уџбеника за неколицину предмета, као и израду јединствене терминологије. ${ }^{22}$

Министарство просвете Србије израдило је 1947. нови наставни план и програм. Број часова наставе историје остао је исти, 3 часа недељно (12\% од укупно $25)$ у трећем и четири часа недељно (15,4\% од 26) у четвртом разреду. У програму је као и раније примењен хронолошко прогресивни принцип. Према новом наставном плану и програму задатак наставе историје је: „1. Да упознаје ученике са прошлошћу наших народа и наше домовине Југославије, да развија љубав и оданост према домовини и њеним народима, да учвршћује братство и јединство и остале тековине народно-ослободилачке борбе, да васпитава децу у непомирљивој мржњи према непријатељима домовине - непријатељима тековина народно-ослободилачке борбе; 2. Да развија код ученика схватање узрочне повезаности историјских догађаја“. ${ }^{23}$

Теме у трећем разреду су биле следеће: живот првобитних људи; стари Словени и њихове сеобе; Јужни Словени у новој постојбини; борбе Јужних Словена за стварање самосталних држава; почеци државног живота (држава карантанских Словена, борбе панонских и далматинских Хрвата за самосталност, ширење хришћанства код Јужних Словена, борбе за стварање српске државе у Рашкој, устанак македонских Словена и стварање македонске државе под Самуилом, устанак у Зети и стварање зетске државе); доба снажења југословенских држава (снажење српске државе у доба Немањића, постанак и снажење босанске државе, Хрвати и Словенци у доба феудализма, Дубровник) и пропадање југословенских феудалних држава.

Наставни програм историје за четврти разред садржавао је следеће теме: југословенски народи под туђинском влашћу; Први и Други српски устанак; буђење националне свести код Јужних Словена у Аустрији и револуција од 1848. године; развој Србије од аутономне области до независне државе; борба Хрвата и Словенаца за политичку и националну слободу; Србија после 1903. године, балкански ратови и Први светски рат; Југославија од 1918-1941. године (Први балкански рат 1912. године - ослободилачки, Други балкански рат 1913-братоубилачки. Први светски рат, узроци и последице; стварање Југославије; Југославија од 1918-1941. године); Други светски рат, слом Југославије, Народноослободилачка борба и њене тековине. У оквиру ове теме обрађени су следећи наставни садржаји: Узроци другог светског рата. Напад на Југославију; издаја, капитулација, окупација и цепање земље; народни издајници и њихова сарадња са окупатором (четници, усташе и др.). Отпор народа и припремање устанка под вођством Комунистичке партије. Напад на СССР.

\footnotetext{
${ }^{22}$ АJ, 315-22-294 до 299.

${ }^{23}$ Наставни план и програм за основне школе, Београд 1947, 8-9.
} 
Први акти саботаже; први партизански одреди. Ширење народног устанка у земљи; развој Народноослободилачке војске од партизанских одреда до Југословенске армије. Непријатељске офанзиве (општи преглед). Вођ Народноослободилачког покрета - маршал Тито. Антихитлеровска коалиција: СССР, САД и Енглеска. Капитулација Италије. Признавање Народноослободилачке борбе од стране савезника. Улога Црвене армије и њени успеси. Сусрет Црвене армије са Народноослободилачком војском и заједничко гоњење непријатеља. Тековине наше борбе: организовање народне власти; прво и друго задедање АВНОЈ-а и њихове главне одлуке. Капитулација Немачке и ослобођење Југославије. Прва антифашистичка скупштина Србије. Антифашистичке скупштине осталих република. Стварање Федеративне демократске Југославије. Устав ФНРЈ. Устав НРС. Југославија као федеративна и народна република; равноправност република и народа Југославије - братство и јединство наших народа. Друштвено-економске промене: народна власт; аграрна реформа и национализација; три сектора народне привреде: социјалистички, задружни и приватни. ${ }^{24}$

У историји за четврти разред, као што се види, детаљно су изучавани не само историја, нарочито историја Народноослободилачке борбе, него и друштвено уређење нове Југославије. Програм је био веома захтеван и преопширан, неприлагођен узрасту ученика, који уз то нису имали уџбенике. Наставници су били у великим тешкоћама да га спроведу, поготово што нису имали никакве приручнике. То су били разлози због којих су овај програм учитељи критиковали у гласилу Министарства просвете Србије - Просветном прегледу. ${ }^{25}$

Због недостатка уџбеника историје, одржавани су курсеви за учитеље који су обучавани за извођење наставе историје. Било је случајева да су предавања са тих курсева скупљена и објављивана као посебно издање да би послужила као незванични приручник за извођење наставе историје. Свет. Ст. Јовановић Цвеја објавио је Потсетник у настави историје. Табаци са курса за учитеље Поиерине одржаног у октобру 1947 године (Шабац 1947, 80 страна). Садржај подсетника је одговарао наставном програму за трећи разред основних школа. На крају књиге дат је подужи списак коришћене литературе, а у додатку терминологија и фразеологија у настави историје. Аутор је своје излагање наглашено заснивао на поставкама марксизма-лењинизма, а та литература му је била један од главних извора који је обилато цитирао.

Комитет за школе и науку при Влади ФНРЈ је крајем октобра 1947. иницирао расправу о дотадашњим резултатима наставе у основним школама, најављујући скуп који ће бити посвећен тој проблематици. ${ }^{26}$ Од 10. до 14. јануара 1948. у Београду у Комитету за школе и науку при Влади ФНРЈ је одржана конференција у вези са питањем основне наставе на којој су учествовали

\footnotetext{
${ }^{24}$ Наставни план и програм за основне школе, Београд 1947, 9-14.

25 Деса Бесараба, Поводом наставног програма из историје за ІІІ разред основне иколе, Просветни преглед, 2-3, 30. јануар 1948, 7.

${ }^{26}$ AJ, 315-18-219.
} 
представници свих народних република. ${ }^{27}$ Међу главним темама били су наставни планови и програми за основне школе, као и настава историје у основним школама. $^{28}$

Нека основна питања везана за извођење наставе историје у основним школама у Србији нису била решена ни неколико година после рата. Главни проблеми били су у конципирању наставних програма, у чему су се испољавале разлике међу републикама, као и у методичком приступу настави историје. Ипак, највећи проблем био је недостатак уџбеника историје, што је схваћено као последица недовољне „идејности“ историјске науке, односно чињенице да није извршена реинтерпретација резултата историјске науке у духу марксизмалењинизма (научног социјализма, односно дијалектичког материјализма). Највиши представници власти били су незадовољни основношколском наставом, уз остало и наставом историје, због чега се настојало на што потпунијем усклађивању основношколске наставе са прокламованим циљевима друштвеног развоја.

${ }^{27}$ AJ, 315-26-94, Комитет за школе и науку при Влади ФНРЈ, Преглед рада конференције по питању основне наставе, одржане у Београду од 10 до 14 јануара 1948.

${ }^{28}$ AJ, 315-26-419, Радован Теодосић, Настава историје у основној школи; види и: Савезна конференција учитеља, педагога и осталих просветних радника о основној настави, Просветни преглед, 2-3, 30. јануар 1948, $1-3$. 


\section{Извори и литература:}

Извори:

Архив Југославије, Београд

Комитет за школе и науку при влади ФНРЈ (ознака фонда:315) 1946-48

Културна политика Југославије 1945-1952. Зборник докумената, приредили Бранка Докнић, Милић Ф. Петровић, Иван Хофман, Београд 2009, књ.1.

Министарство просвете Владе ФНРЈ (ознака фонда:313) 1945-46

Наставни план и програм за основне школе, Београд 1947.

Нови наставни план и програм за основне школе са методским упутствима за обраду појединих наставних предмета, Београд 1945.

Савезна конферениија учитеља, педагога и осталих просветних радника о основној настави, Просветни преглед, 2-3, 30 .јануар 1948.

Службени лист ФНРЈ

Литература:

Бесараба, Деса, Поводом наставног програма из историје за III разред основне школе, Просветни преглед, 2-3, 30.јануар 1948.

Богавац, Томислав, Школство у Србији на путу до реформе (развој школа 1945-1975), Београд 1980.

Бонџић, Драгомир, Просвета и наука у Србији 1945-1990, Историја 20.века 2, Београд 2008.

Dimić, Ljubodrag, Agitprop kultura. Agitpropovska faza kulturne politike u Srbiji 1945-1952, Beograd 1988.

Зихерл, Борис, Задаци нашег школства и научних установа, Савремена школа, 3. септембар 1946.

Obradović, Marija, 'Narodna demokratija' u Jugoslaviji 1945-1952, Beograd 1995.

Павловић, Момчило, Школство у Србији 1945-1950, Образовање Срба кроз векове, Београд 2003. 


\title{
TOWARDS NEW HISTORICAL CONCIOUSNESS: HISTORY TEACHING IN PRIMARY SCHOOLS IN SERBIA FROM 1945 TO 1947
}

\begin{abstract}
Summary
In the period from 1945 to 1947, the new communist authorities sought to emphasize its legitimacy as much as possible, which was based on changes made during the liberation war and revolution. The war and revolution changes had a special place in the public discourse, being understood as a main tool for shaping historical awareness of young generations. Accordingly, there were made changes in curricula of the history teaching in primary schools. In the second half of May 1945, Ministry of Education of Serbia brought the curriculum for primary schools with methodological guidelines for teaching certain subjects. History was studied in the third grade with three hours per week (out of 27 in total), while the four grade studied history four hours per week (out of 29 in total). The curriculum arrangement in the third and the fourth grade was a combination of chronological and progressive principle with the principle of concentric circles. On 28 September 1945, DFY Minister of Education, Vladimir Ribnikar, prescribed the Framework Curriculum for Primary Schools. This curriculum was different in certain respect than the curriculum published by the Ministry of Education of Serbia. The prevailing principle in the Framework Plan was chronologically progressive. The only teaching topic that was repeated both in the third and the fourth grade was the topic of the National Liberation Struggle. Religious education became an optional subject. In the new curriculum, which was drafted by the Ministry of Education of Serbia in 1947, a number of hours of the history teaching remained the same, 3 hours per week (out of 25in total) in the third grade, and four hours per week (out of 26 in total) in the fourth grade. As previously, the curriculum implemented chronologically progressive principle. It was realized very soon that the reduction of the overall history teaching to the National Liberation Struggle was completely useless and not educative, and that it was necessary to establish a new approach to the history teaching.
\end{abstract} textbooks

Keywords: Yugoslavia, Serbia, primary school, history teaching, curricula, 